\title{
English Major Students' Perceptions Towards Watching English Movies In Listening And Speaking Skills Development
}

\author{
Nihta V. F. Liando \\ English Education Study Program, \\ Manado State University \\ Ray J. V. Sahetapy \\ English Education Study Program, \\ Manado State University \\ Mister G. Maru \\ English Education Study Program, \\ Manado State University
}

\begin{abstract}
The aim of the study was to find out English major students' perceptions towards watching English movies to develop listening skill and speaking skill. This study was conducted at one university in North Sulawesi, specifically on the students who took Listening and Speaking class. The instrument used in the data collection was a questionnaire that consists of three parts for finding out the background of the respondents, English movie watching perceptions, and level agreement towards English movies. The data were analyzed using Microsoft Excel and shown in tables of frequency, percentage and mean. The findings indicated that English major students are aware that they can improve their listening skill by watching English movies. Subtitles also can help respondents to understand conversation in the movies, and English movies are believed to be more effective than other media as teaching tools. English major students also believe that they can improve their speaking skill by watching English movies. Students think watching English movies has more direct influence to listening skill compared to speaking skill. Future studies are recommended to conduct interviews of students to gain more information or arrange a test of student listening and speaking skills. Other interesting topics would be to study further about whether English subtitles or Indonesian subtitles is more effective as learning media, and also which movie genre is more effective in English skills development.
\end{abstract}

Keywords: students' perceptions, English movies, listening skill, speaking skill, EFL learning, university

\section{INTRODUCTION}

Communication is always important in everyday life. People need to communicate by using language to interact with other people and to express their feelings or share ideas and thoughts. In order to communicate, everybody has automatically learned their native language through their social environment since they were children. However, at the international level, we are demanded to be able to communicate well not only in our own language but also by using an international language like English.

Out of all four language skills mentioned, the oral skills, which are listening and speaking, are the basic skills needed for communication. Listening is the ability to identify and understand 
what others are saying. Without a good listening skill, we cannot have a successful conversation (Howatt \& Dakin, 1974). Speaking is an interactive process of constructing meaning that involves producing, receiving and processing information (Brown, 1994; Burns \& Joyce, 1997). A speaker's skills and speech habits have an impact on the success of any exchange (Van Duzer, 1997). Therefore, it is obvious that we cannot communicate or learn English language effectively if we lack good English listening and speaking skills.

English major students at one university in North Sulawesi, which are the subjects of this study, are required to use English in their daily activities in campus; therefore, with all their textbooks in English, full English lectures in class, and all assignments in English, it is important for them to have good and developed English skills, especially oral skills. But of course with varied demographic background of the students, their abilities in oral skills are also varied. So, it is important for them to have their own motivation to develop their listening and speaking skills.

Lindsay and Norman (1977) described perception as one's ultimate experience of the world and typically involve further processing of sensory input, such as through eyes, ears, nose, etc. Students must have experienced many kinds of English learning methods, whether in a class, group learning, or even independent learning in practice, as well as for the English major students at this one university in North Sulawesi, they have been exposed to many kinds of learning methods. For instance, there are more traditional methods and also more modern ones with audio, visual and others. With the variety of methods used in language teaching, these students must have their own perceptions in those methods especially in the perspective of which method is more effective for English skills development.

In the modern society, media play an important role in English learning. English movie is one of the effective media for improving students' listening skills (Brown \& Yule, 1983). Moreover, most students think movies are the easiest English media to improve their English skills (Winiyakul, 2010). They can pay attention and be happy to learn English because they can enjoy the movies and improve their English skills along the way.

Nowadays, these students at this one university already possess their own personal media devices, such as laptop, PC (personal computer), or even smaller gadgets like smartphones and tablets. One of the things they do with their devices is watching movies from DVDs, online streaming, or video files downloaded from the internet. These students tend to share movie files with each other among their community in the dormitories inside the campus or even outside at rented houses and watch the movies in their free times.

Talking about watching movies in free times, these students at this one university must have different behaviours and perspectives on how they see the influence of English movies in their listening and speaking skills development. Tafani (2009) suggested that students should be encouraged to see as many movies as possible outside the classroom or parts of movies in the classroom. So, their frequencies of watching English movies also influence the effects on English listening and speaking skills development. Hence, some people are aware of the influence of English movies in their listening and speaking skills development, but undoubtedly there are people who are not as well and just watch movies for fun. Therefore, based on all the descriptions above, the researcher decided to conduct a research in finding out the perceptions of English major students towards watching English movies in listening and speaking skills development.

This study aims to answer these questions: 
1. How are English major students' perceptions towards watching English movies to develop listening skill?

2. How are English major students' perceptions towards watching English movies to develop speaking skill?

This research has the following objectives:

1. To identify English major students' perceptions towards watching English movies to develop listening skill.

2. To identify English major students' perceptions towards watching English movies to develop speaking skill.

This study focuses on exploring the perceptions of the English major students at one university in North Sulawesi, specifically those who took Listening and Speaking class at the time of the research being conducted, towards watching English movies in listening and speaking skills development, because those students were more relevant respondents to have their based on experience perceptions shared regarding listening and speaking skills development.

The implications of the study are divided into two perspectives, theoretical and practical. This study theoretically could help the enrichment of language education. The findings of the study could give contribution to the EFL learning, specifically in students' perceptions towards English learning methods.

In practical, the findings of the study could be used to encourage students to be more aware of the good effects of watching English movies to develop their English listening and speaking skills, or even in language skills development in general. Students, therefore, may realize that the process of improving English listening and speaking skills can be fun and educational at the same time. This study in practical could also encourage teachers to consider more about the use of English movies as media of EFL teaching in classrooms, which also could involve the schools and educational institutions, so they could be more aware of the importance of using movies in education, and be motivated to provide more media in education especially the use of movies in EFL learning and language skills development.

Lindsay and Norman (1977) stated that perception is the process by which organisms interpret and organize sensation to produce a meaningful experience of the world. Perception refers to the one's ultimate experience of the world typically involves further processing of sensory input (Lindsay and Norman, 1977). Perception involved more process of thinking as a result of the information received from the sensory systems regards certain things or events. It is output process where the judgments or beliefs were produced by an individual and it influenced the way they think and feel (Ahen, 2009). Perception Definition by MerriemWebster (n.d.) defines perception as awareness of the elements of environment through physical sensation that is interpreted in the light of experience. Other definitions of perception for English language learners by Perception Definition by Merriem-Webster (n.d.):

- the way you think about or understand someone or something

- the ability to understand or notice something easily

- the way that you notice or understand something using one of your senses

Perception is the root of thinking which invoke certain judgments or beliefs that influence human attitude (Ahen, 2009). Hence, this study was conducted in order to specifically identify the perceptions, the way the English major students think or feel, towards watching English movies in the development of their own listening and speaking skills, based on the experience and awareness. 


\section{Listening Skill}

According to Wills (2006) listening is one of the most important components in all five English competences; therefore, listening deserves particular attention. Rivers (1966) claimed that speaking does not of itself constitute communication unless what is said is comprehended by another person. Comprehension of spoken speech is therefore a primary importance of the communication aim is to be reached. The listening process involves understanding a speaker's accent or pronunciation, the speaker's grammar and vocabulary, and comprehension of meaning. Dunkel (1986) asserts that developing proficiency in listening skill is the key to achieving proficiency in speaking.

Harmer (2000) agrees that listening is special because listening comprehension is a process of receiving, processing, and interacting with the relevant knowledge which our mind has to complete instantly. The definition of listening includes "active listening", goes beyond comprehending as understanding the message content, to comprehension as an act of empathetic understanding of the speaker (Thomlison, 1984). According to Kijpoonphol (2008), new vocabulary, slang, and idioms are obstacles to listening skill. Also, the topic being spoken, the rate of delivery, redundancy, and prosodic features are factors that affect listening skill. Students do not have an innate understanding of what effective listeners do; therefore, it is the responsibility of teachers to share that knowledge with them and the most valuable way to teach listening skills is for teachers to model them themselves, creating an environment which encourages listening (Gilakjani \& Ahmadi, 2011).

\section{Speaking Skill}

Hornby (1995) defines that speaking is making use of words in an ordinary voice, offering words, knowing and being able to use a language expressing one-self in words, and making speech. Speaking skill is the skill to perform the linguistics knowledge in an actual communication, thus, by speaking with others, we are able to know what kinds of situation are in the world (Ismiati, 2012). Speaking is the process of building and sharing meaning through the use of verbal and non-verbal symbol in a variety of context (Chaney, 1998). Speaking is one of the four basic competences that students should gain well. It has an important role in learning language, because practically the main purpose of learning language is being able to communicate.

Speaking is the productive skill. It could not be separated from listening. Communication is a two-way process involving the speaker and the listener. Communication can only be considered effective if both aspects are achieved successfully. When we speak we produce the text and it should be meaningful. In the nature of communication, we can find the speaker, the listener, the message and the feedback. Speaking could not be separated from pronunciation as it encourages learners to learn the English sounds. Speaking is one of the most difficult skills language learners have to face (Bueno, Madrid and Mclaren, 2006). Indeed, one frustration commonly voiced by learners is that they have spent years studying English, but still they cannot speak it.

Human communication is a complex process. People need communication when they want to say something, transmit information or need to speak. Speakers use communication when they want to express or inform someone about something. They use language according to their purpose and it is necessary for there to be a listener and a speaker for effective communication (Harmer, 2007). Many English teachers claim that the best way to acquire speaking skills is by interacting (Alonso, 2013). This aim is fulfilled by means of communicative language teaching and collaborative learning. Communicative language teaching is based on real-life situations 
that require communication. Following this method, there will be opportunities for the students to communicate in the target language.

\section{Media in Learning}

According to Erita Budi (2012), media are any devices that assist an instructor to transmit to learner facts, skills, attitudes, knowledge and appreciation or additional materials used when using a particular teaching method to make learning easy, as it intends to help both the teacher to teach more reflectively and the learner to grasp the concepts more effectively. Roblyer et al (2010) states media such as slides and films delivered information in more concrete and therefore more effective ways than lectures and books did.

Anderson (1976) classifies media into ten categories as follows:

1. Audio (e.g. audio tapes, radio, $\mathrm{CD}$, telephone)

2. Print (e.g. textbooks, modules, brochures, leaflets, pictures)

3. Audio-print (e.g. audio tapes that include written materials

4. Visual silent Projection (e.g. overhead transparency, film frames /slides)

5. Audio visual projection silent (e.g. voiced film frames/slides)

6. Visual Motion (e.g. silent film)

7. Audio Visual motion (e.g. motion film, video, TV)

8. Physical Objects (e.g. real objects, models, specimens)

9. Humans and the environment (e.g. teacher, librarian, laboratory)

10. Computer (e.g. CAI: Computer Assisted Instructional, CMI: Computer Managed Instructional)

This present study relates to the use of audio-visual media in language learning, to be precise in listening and speaking skills development. Movie is an audio-visual kind of media, because movies produce both motion picture and sound at the same time. Farooq (2014) mentioned that with audio-visual kind of media, all learning material make the learning situations as real as possible and give us firsthand knowledge through the organs of hearing and seeing.

Therefore, any device can be used to make the learning experience more concrete and effective, more realistic and dynamic can be considered audio-visual material. We learn through our sense organs. Senses are the ways of knowledge. All the sense organs help us in understanding the environment. Most of the knowledge, which we acquire from school, comes through our ears and eyes. Therefore, movie is a good example of media that stimulate the senses of seeing and hearing.

\section{Movies in Listening and Speaking Skills Development}

The English movie is one of media which can be used to improve students' listening and speaking skills. The movies along with the movies' script are widely used as a teaching method in English lessons; however, practice in class only is never enough. As Wills (2006) mentioned, successful listening skills are acquired over time and with lots of practice.

One of the advantages of using the movie is that visual images stimulate student's perceptions directly, while written words can do this indirectly. Films are more sensory experience than reading, besides verbal language, there is also color, movement, and sound. Movie-based experimental class was livelier and the students were more interested in following the lesson carefully. Movie-viewing experiences further created more student-teacher and studentstudent discussions. Films draw students' attention and captured their interest (Xhemaili, 2013). 
There are several reasons why using English movies as a tool to improve English listening and speaking skills is an appropriate approach.

First, movies are accepted to be the most authentic material that teachers can provide in a classroom situation according to the idea that movies can bring real life into the classroom (Lonergan, 1984). The second reason is that movies have the power to motivate people to listen and pay attention to the target language. Movies are generally made for entertainment, and aim to impress the audiences; therefore, they are more interesting and enjoyable when compared to the video materials made for language teaching purposes. Third, movies provide visual context that the students can understand the story by watching situations and consider what pronoun is indicated or what the speaker really wants to say. By watching movies, students will have the opportunity to experience the semi-real communication in face to face interactions. Fourth, by watching movies students will also gain socio-cultural information that can be easily acquired by seeing it on the visual medium. Students will learn about the cultural non-verbal language, for instance, student will know how to respond verbally and paralinguistically when communicating by using space and gesture (Rubin, 1984). The final reason is that movies provide meaningful contexts and vocabulary with natural language spoken at a natural flow of speed. Students will get used to the real conversation in everyday life which is considered very important.

However, despite all the reason mentioned above, there are also some disadvantages to using movies as a tool to improve listening and speaking skills too. If teachers cannot use movies in a right way during their teaching, the movie class still won't be successful (Chenchen, 2011). The whole movie might not be appropriate for classroom teaching. In that condition, students should be encouraged to participate in learning activities that are related to the movie. For example, students should be encouraged to pay attention to the collocations or chunks of language while watching the movies, to repeat in their minds the expressions in current use and to parrot the words that they can understand but cannot use. If there is no activity for them, students will only watch the movie for entertainment (Pimsamarn, 2011).

Another problem is that sometimes the language in a movie is too difficult and too rapid for foreign language learners who have limited linguistic competence. Therefore, movies seem to be a suitable choice for advanced learners only (Sato, 2007). Even though it is believed that watching movies can help students improve their oral skills, however, we still have one more thing to be concerned about, which are the subtitles. Several studies concerning film subtitles have demonstrated support for the use of subtitles; however, whether to apply the first (L1) or the target language (L2) subtitles as a better option remains unclear (Pimsamarn, 2011).

Watching films with the target language subtitles (English) is useful for not only L1 but also L2 learning. When students are exposed to all images, sounds and L2 texts, everything will be much easier to comprehend for the students. The image will give a clue to the meaning, and the L2 texts will help students to identify the words that they are familiar with. Nevertheless, while watching movies with L2 subtitles, the students might be distracted by the target language texts and end up paying less attention to the images and the sounds. Watching films with the subtitles of the students' first language, students' attention is drawn not only to the translated texts but also to the sounds; therefore students will be able to confirm their understanding of what they hear with the translation texts. However, students may not pay attention to what they actually hear, but to the written text, because they have stronger reading skills in their native language, compared with their target language reading and listening skills (Pimsamarn, 2011). 


\section{RESEARCH METHOD}

The target population of this study is English major students at one university in North Sulawesi. The sample of this study is 67 English major students who took Listening and Speaking class at one university in North Sulawesi. The research instrument in this study is a questionnaire asking about the subjects' movie watching perceptions on watching English movies to develop listening and speaking skills. The questionnaire that was used is mainly based on Pimsamarn (2011)'s questionnaire which was used at Thammasat University, Bangkok.

The questionnaire consists of three main parts. The first part covers the background of the respondents to gather personal information of the students. The second part is about students' English movie watching perceptions. The last part covering the agreement level towards watching English movies, which consists eighteen items of statements with level of agreement in a Likert scale related to listening and speaking skills development. The questionnaires were distributed to the sixty-seven English major students who took Listening and Speaking class at one university in North Sulawesi. The respondents were asked to complete the questionnaires, the researcher waited for them to complete in order to ensure that one hundred percent of the questionnaires returned.

After the data collection, the data from questionnaires were transformed into numbers and analyzed using Microsoft Excel. The researcher basically counted the responses per item manually then input the total number of each option of an item, then used the formula to percentage the chosen option per number of all samples which is 67. The findings are presented in descriptive statistics which include tables of frequency and percentage.

\section{Gender}

\section{FINDINGS}

According to the result, most of the respondents were females $(71.6 \%)$ and the rest were males $(28.4 \%)$.

\begin{tabular}{|l|ll|r|}
\hline Gender & $\begin{array}{l}\text { Frequency of } \\
\text { Student }\end{array}$ & Percentage \\
\hline \hline Male & & 19 & $28.4 \%$ \\
\hline Female & & 48 & $\mathbf{7 1 . 6} \%$ \\
\hline \hline Total & & 67 & $100.0 \%$ \\
\hline
\end{tabular}

\section{Background of English Study}

\begin{tabular}{|l|r|r|}
\hline Years & $\begin{array}{l}\text { Frequency } \\
\text { of Student }\end{array}$ & Percentage \\
\hline \hline$<5$ years & 11 & $16.4 \%$ \\
\hline $5-9$ years & 16 & $23.9 \%$ \\
\hline $10-12$ years & 26 & $\mathbf{3 8 . 8 \%}$ \\
\hline $13-15$ years & 11 & $16.4 \%$ \\
\hline$>15$ years & 3 & $4.5 \%$ \\
\hline \hline Total & 67 & $100.0 \%$ \\
\hline
\end{tabular}

The result obtained shows that the majority of the respondents (38.8\%) have been studying English for 10-12 years, followed by $23.9 \%$ of 5-9 years studying time, then followed by $16.5 \%$ of both $<5$ years and 13-15 years, while $4.5 \%$ of them claimed that they have studied English for more than 15 years. 


\section{Frequency of Daily English Use}

The largest number of the respondents at 38.8\% $(n=26)$ responded that they use English every day, followed by 4-6 times a week at 34.3\% (n=23). Whereas, $26.9 \%(n=18)$ of the respondents use 1-3 times a week.

\begin{tabular}{|l|r|r|}
\hline $\begin{array}{l}\text { Frequency of } \\
\text { Daily English Use }\end{array}$ & $\begin{array}{l}\text { Frequency } \\
\text { of Student }\end{array}$ & Percentage \\
\hline \hline 1-3 days/week & 18 & $26.9 \%$ \\
\hline 4-6 days/week & 23 & $34.3 \%$ \\
\hline Everyday & 26 & $\mathbf{3 8 . 8 \%}$ \\
\hline \hline Total & 67 & $100 \%$ \\
\hline
\end{tabular}

\section{Frequently Used English Skills}

\begin{tabular}{|l|r|r|}
\hline English Skills & $\begin{array}{l}\text { Frequency } \\
\text { of Student }\end{array}$ & Percentage \\
\hline \hline Listening & 23 & $\mathbf{3 4 . 3 \%}$ \\
\hline Speaking & 20 & $29.9 \%$ \\
\hline Reading & 21 & $31.3 \%$ \\
\hline Writing & 3 & $4.5 \%$ \\
\hline \hline Total & 67 & $100 \%$ \\
\hline
\end{tabular}

On consideration of which English skill is most frequently used by the respondents, it was found that $34.3 \%$ of the respondents claimed that they use English listening skill most frequently in their overall daily English skill practice. The second most frequently used skill is reading at $31.3 \%$, followed by speaking skill at $29.9 \%$, and the least is writing at $4.5 \%$.

\section{Respondents' Perceptions on Watching English Movies Movie Watching Frequency}

According to the data, the majority of the respondents (37.3\%) watch English movies 3-5 times a week, followed by once a week with 19 students (28.4\%), then 12 students $(17.9 \%$ of the respondents) claimed that they watch English movies more than 5 times in a week, and the least is less than a week (16.4\%), which who could watch movies only once in two weeks or less. There are more than $50 \%$ overall watch movies more than 3 times a week. From this finding, most of the respondents apparently have a hobby to watch movies in their free times by their own will.

\begin{tabular}{|l|r|r|}
\hline $\begin{array}{l}\text { Frequency of } \\
\text { watching } \\
\text { movies }\end{array}$ & $\begin{array}{l}\text { Frequency } \\
\text { of Student }\end{array}$ & Percentage \\
\hline \hline$>5 /$ week & 12 & $17.9 \%$ \\
\hline $3-5 /$ week & 25 & $\mathbf{3 7 . 3 \%}$ \\
\hline 1/week & 19 & $28.4 \%$ \\
\hline$<1 /$ week & 11 & $16.4 \%$ \\
\hline \hline Total & 67 & $100.0 \%$ \\
\hline
\end{tabular}

Subtitle Preferences

\begin{tabular}{|l|r|r|}
\hline $\begin{array}{l}\text { Subtitles } \\
\text { Language }\end{array}$ & $\begin{array}{l}\text { Frequency } \\
\text { of Student }\end{array}$ & Percentage \\
\hline \hline Indonesian & 31 & $46.3 \%$ \\
\hline English & 36 & $53.7 \%$ \\
\hline \hline Total & 67 & $100 \%$ \\
\hline
\end{tabular}


From these percentages, it shows that apparently most students are aware of the use of subtitles, especially English, whether because of the fact that they mostly have better English competence or they use it to learn more English, they could have different motivations of why they prefer English.

\section{Movie Genre Preferences}

\begin{tabular}{|l|r|r|}
\hline Movie Genre & $\begin{array}{c}\text { Frequency } \\
\text { of Student }\end{array}$ & Percentage \\
\hline \hline Horror & 6 & $9.0 \%$ \\
\hline Comedy & 13 & $19.4 \%$ \\
\hline Romance & 22 & $32.8 \%$ \\
\hline Action & 25 & $37.3 \%$ \\
\hline Other: Religious & 1 & $1.5 \%$ \\
\hline \hline Total & 67 & $100 \%$ \\
\hline
\end{tabular}

Apparently more students prefer to watch action movies and romance movies. So, these kinds of movies could be just hobbies that they prefer or these could be kinds of movies that are effective for English teaching tool. The variety of this movie genre preferences yield more questions of what movie genre is the most effective to be used in language development.

\section{Motivation to Watch English Movies}

This shows that apparently most of the respondents are aware that watching English movies help them to develop their overall English language skills, though $20 \%$ of the respondents are still not aware of that.

\begin{tabular}{|l|r|r|}
\hline Motivation & $\begin{array}{l}\text { Frequency } \\
\text { of Student }\end{array}$ & Percentage \\
\hline \hline Entertainment & 14 & $20.9 \%$ \\
\hline Skill Improvement & 45 & $67.2 \%$ \\
\hline Both & 8 & $11.9 \%$ \\
\hline \hline Total & 67 & $100 \%$ \\
\hline
\end{tabular}

\section{Agreement Level towards Watching English Movies}

\section{Students' Level of Agreement on English Skills}

The majority of the respondents $(46.3 \%$ at high level) claimed that subtitles helped them understand the conversation in the movie better. Most of the overall respondents $37.3 \%$ at high level and 34.3\% at very high level) agreed that watching English movies can be beneficial for English use in everyday life.

\begin{tabular}{|l|c|c|c|c|c|}
\hline \multirow{2}{*}{} & \multicolumn{5}{|c|}{ Level Of Agreement } \\
\cline { 2 - 6 } & $\mathbf{5}$ & $\mathbf{4}$ & $\mathbf{3}$ & $\mathbf{2}$ & $\mathbf{1}$ \\
\hline \hline $\begin{array}{l}\text { 1. English } \\
\text { subtitles help } \\
\text { you understand } \\
\text { conversation in } \\
\text { the movies } \\
\text { better. }\end{array}$ & 16 & $\mathbf{3 1}$ & 19 & 1 & 0 \\
\cline { 2 - 6 } & $23.9 \%$ & $\mathbf{4 6 . 3} \%$ & $28.4 \%$ & $1.5 \%$ & $0.0 \%$ \\
\hline $\begin{array}{l}\text { 16. Watching } \\
\text { English movies } \\
\text { can be beneficial } \\
\text { for English use in } \\
\text { everyday life. }\end{array}$ & $34.3 \%$ & $\mathbf{3 7 . 3 \%}$ & $26.9 \%$ & $1.5 \%$ & $0.0 \%$ \\
\cline { 2 - 6 } & & $\mathbf{2 5}$ & 18 & 1 & 0 \\
\hline
\end{tabular}




\section{Students' Level of Agreement on Listening Skill}

Twenty nine respondents (43.3\%) agreed that they learn correct pronunciation through movies, also the same amount and percentage of respondents believed that they could understand unfamiliar accents and dialects better. Thirty seven of the respondents $(55.2 \%$ at very high level) agreed that they learn new vocabularies from English movies. However, the majority of the respondents (47.8\%) only moderately think that they understand unfamiliar idioms, proverbs, and slang better.

\begin{tabular}{|c|c|c|c|c|c|}
\hline & \multicolumn{5}{|c|}{ Level of Agreement } \\
\hline & 5 & 4 & 3 & 2 & 1 \\
\hline \multirow{2}{*}{$\begin{array}{l}\text { 2. Learn correct } \\
\text { pronunciation } \\
\text { through movies. }\end{array}$} & 19 & 29 & 15 & 4 & 0 \\
\hline & $28.4 \%$ & $43.3 \%$ & $22.4 \%$ & $6.0 \%$ & $0.0 \%$ \\
\hline \multirow{2}{*}{$\begin{array}{l}\text { 4. Understand } \\
\text { unfamiliar } \\
\text { accents and } \\
\text { dialects better. }\end{array}$} & 8 & 29 & 25 & 5 & 0 \\
\hline & $11.9 \%$ & $43.3 \%$ & $37.3 \%$ & $7.5 \%$ & $0.0 \%$ \\
\hline \multirow{2}{*}{$\begin{array}{l}\text { 6. Learn new } \\
\text { vocabularies. }\end{array}$} & 37 & 23 & 5 & 2 & 0 \\
\hline & $55.2 \%$ & $34.3 \%$ & $7.5 \%$ & $3.0 \%$ & $0.0 \%$ \\
\hline \multirow{2}{*}{$\begin{array}{l}\text { 8. Understand } \\
\text { unfamiliar } \\
\text { idioms, proverbs, } \\
\text { and slang better. }\end{array}$} & 6 & 19 & 32 & 9 & 1 \\
\hline & $9.0 \%$ & $28.4 \%$ & $47.8 \%$ & $13.4 \%$ & $1.5 \%$ \\
\hline \multirow{2}{*}{$\begin{array}{l}\text { 10. Motion } \\
\text { pictures in the } \\
\text { movies help you } \\
\text { understand the } \\
\text { conversation } \\
\text { better. }\end{array}$} & 16 & 32 & 15 & 4 & 0 \\
\hline & $23.9 \%$ & $47.8 \%$ & $22.4 \%$ & $6.0 \%$ & $0.0 \%$ \\
\hline \multirow{2}{*}{$\begin{array}{l}\text { 12. English } \\
\text { movies can } \\
\text { improve your } \\
\text { listening skill } \\
\text { better than other } \\
\text { English media } \\
\text { normally used in } \\
\text { class. }\end{array}$} & 24 & 22 & 20 & 1 & 0 \\
\hline & $35.8 \%$ & $32.8 \%$ & $29.9 \%$ & $1.5 \%$ & $0.0 \%$ \\
\hline \multirow{2}{*}{$\begin{array}{l}\text { 14. English } \\
\text { movies are good } \\
\text { for teaching } \\
\text { listening for } \\
\text { students. }\end{array}$} & 21 & 27 & 18 & 1 & 0 \\
\hline & $31.3 \%$ & $40.3 \%$ & $26.9 \%$ & $1.5 \%$ & $0.0 \%$ \\
\hline \multirow{2}{*}{$\begin{array}{l}\text { 17. You can } \\
\text { improve your } \\
\text { listening skill by } \\
\text { watching English } \\
\text { movies. }\end{array}$} & 21 & 34 & 10 & 2 & 0 \\
\hline & $31.3 \%$ & $50.7 \%$ & $14.9 \%$ & $3.0 \%$ & $0.0 \%$ \\
\hline
\end{tabular}

Most students (47.8\% at high level) agreed that motion pictures in the movies help them understand conversation better. The majority of the respondents (35.8\% at very high level) agreed that English movies can improve listening skill better than other English media normally used in class. Twenty seven students (40.3\%) agreed that English movies are good for teaching listening for students, and also the majority of the students $(50.7 \%$ at high level) agreed that they can improve listening skill by watching English movies. 


\section{Students' Level of Agreement on Speaking Skill}

The majority of the respondents (46.3\% at a high level) claimed that they apply correct pronunciation in practice through movies.

\begin{tabular}{|l|c|c|c|c|c|}
\hline & \multicolumn{5}{|c|}{ Level 0f Agreement } \\
\cline { 2 - 6 } & $\mathbf{5}$ & $\mathbf{4}$ & $\mathbf{3}$ & $\mathbf{2}$ & $\mathbf{1}$ \\
\hline \hline $\begin{array}{l}\text { 3. Apply correct } \\
\text { pronunciation in } \\
\text { practice through } \\
\text { movies. }\end{array}$ & 12 & $\mathbf{3 1}$ & 22 & 2 & 0 \\
\hline $\begin{array}{l}\text { 5. Apply } \\
\text { unfamiliar accents } \\
\text { and dialects } \\
\text { better. }\end{array}$ & $\mathbf{1 7 . 9 \%}$ & $\mathbf{4 6 . 3 \%}$ & $32.8 \%$ & $3.0 \%$ & $0.0 \%$ \\
\hline $\begin{array}{l}\text { 7. Apply new } \\
\text { vocabularies in } \\
\text { practice through } \\
\text { movies. }\end{array}$ & $19.4 \%$ & $\mathbf{4 7 . 8 \%}$ & $32.8 \%$ & $0.0 \%$ & $0.0 \%$ \\
\hline $\begin{array}{l}\text { 9. Apply more } \\
\text { idioms, proverbs, } \\
\text { and slang in } \\
\text { practice through } \\
\text { movies. }\end{array}$ & $9.0 \%$ & $26.9 \%$ & $\mathbf{4 6 . 3} \%$ & $16.4 \%$ & $1.5 \%$ \\
\hline $\begin{array}{l}\text { 11. Motion } \\
\text { pictures in the } \\
\text { movies inspire } \\
\text { you in practicing } \\
\text { better daily } \\
\text { conversations. }\end{array}$ & $29.9 \%$ & $\mathbf{3 8 . 8} \%$ & $25.4 \%$ & $6.0 \%$ & $0.0 \%$ \\
\hline $\begin{array}{l}\text { 13. English } \\
\text { movies can } \\
\text { improve your } \\
\text { speaking skill } \\
\text { better than other } \\
\text { English media } \\
\text { normally used in } \\
\text { class. }\end{array}$ & $22.4 \%$ & $\mathbf{4 3 . 3 \%}$ & $34.3 \%$ & $0.0 \%$ & $0.0 \%$ \\
\hline $\begin{array}{l}\text { 15. English } \\
\text { movies are good } \\
\text { for teaching } \\
\text { speaking for } \\
\text { students. }\end{array}$ & $28.4 \%$ & $\mathbf{4 6 . 3 \%}$ & $25.4 \%$ & $0.0 \%$ & $0.0 \%$ \\
\hline $\begin{array}{l}\text { 18. You can } \\
\text { improve your } \\
\text { speaking skill by } \\
\text { watching English } \\
\text { movies. }\end{array}$ & $34.3 \%$ & $\mathbf{4 0 . 3 \%}$ & $20.9 \%$ & $4.5 \%$ & $0.0 \%$ \\
\hline
\end{tabular}

Most of them, though, only moderately think that they apply unfamiliar accents and dialects better (47.8\%), and also idioms, proverbs, and slang in practice (46.3\%). Thirty two of them (47.8\% at high level) believed that they apply new vocabularies in practice through movies. Twenty six students (38.8\%) highly agreed that motion pictures inspire them to practice better daily conversations.

Twenty nine respondents (43.3\% at high level) agreed that English movies can improve speaking skill better than other English media normally used in class. Thirty one respondents (46.3\%) agreed that English movies are good for teaching speaking skill, while also most of 
them (40.3\% at high level) of them believed that they can improve speaking skill by watching English movies.

Based on the comparison of percentages of the findings and overall average level of agreement on the respondents' perceptions towards watching English movies in listening skill development with scale average 3.91 and their perceptions towards watching English movies in speaking skill development with 3.75 average of scale, with only by 0.16 difference, it is shown that watching English movies have more direct influence to listening skill compared to speaking skill.

\section{DISCUSSION}

The aim of this study is to identify the perceptions of English major students at one university in North Sulawesi on the effect of watching English movies in their listening skill and speaking skill development. According to the findings, the students have positive response regarding watching English movies in developing both oral skills.

From the perspective focusing on listening skill development, the students believe that they can develop their listening skill through watching English movies. According to the findings, they believe that they learn better pronunciation through English movies. As English major students who are expected to use English as daily as possible, as seen in the findings how the majority of the students $(34.3 \%$ high $+38.8 \%$ very high) claimed that they use English every day, they must have their own ways to be more fluent from time to time. With this finding, it shows that movies could be one of the effective ways they have been using to improve their listening skill. Practicing listening comprehension with native speakers is always the best way, but it is not common to always meet foreign people to practice every day, but by using movies, we can practice our English listening skill from mother tongue speakers easily only by videos. And the students mostly are aware of this importance of movies this way.

From the result, they also agreed that they are able to understand even unfamiliar accents and dialects better. Having the ability to listen to fellow EFL speakers is a good skill, but being able to comprehend native English speakers with different kinds of unfamiliar dialects and accents, is another level of skill. The fact that most students believe that they could understand different accents and dialects through movies is noteworthy. The finding does not contradict at all about it, how mostly of the students (34.3\%) really used listening skill more often than the others. It could be because listening is the first skill we encounter in English skills developments. So, it shows that most of them are already aware of the impact of movies in practicing listening skill.

The majority of the students believe that they learn new vocabularies through movies. Another good point, they could learn whole new words through movies. By listening more to English native speakers they believe that they can understand and add more words to their own vocabularies. This finding is supported with the fact that they use of subtitles, especially English subtitle (53.7\%). Because by using English subtitles, it is easier to learn new vocabularies from movies.

However, at the point of understanding unfamiliar idioms, proverbs, and slang better, they only moderately think that they are able to do that. It is because in English language learning, grammar, vocabularies and pronunciation are basically the first things covered by foreign language learners, but when it comes to idioms, phrases, even proverbs and slang; it needs more natural acquisition with good intake ability not easily only by learning in school. Therefore, the students might not be too agreeable in this point, though they actually could 
learn more if they take good advantage of the use of subtitles, and also of course with more focused motivation in watching movies, they could learn better.

They believe that motion pictures in movies help them understand the conversation better. Movie is an audio-visual kind of media, with senses that humans have, it stimulate people to see and to hear. With more realistic aids such as movies, it affects the students to be able to understand the language in context of different kinds of conversation, especially by having motivation in watching English movies for skill improvement which is relevant with the finding (67.2\%), they could really learn and understand the conversation contextually.

The concluding point in listening skill development based on the findings is they very highly believe that they can improve their listening skill better than other media that are normally used in class. As English major students, they have been learning language with different kinds of media, such as print, visual, audio, and audio-visual. This fact is supported with the finding; the more frequent they watch English movies (37.3\%), the more they realize how effective movies are as media for listening skill development.

Another point is that they believe that English movies are good for teaching listening skill for students. From these findings, it is found that they believe the use of audio-visual media, e.g. videos, movies, in classrooms is the more effective as media of language learning. The recapitulated point overall of the findings on watching movies in listening skill development is the students believe that they can improve their listening skill by watching English movies.

From the perspective of watching English movies to develop speaking skill, the overall students believe that they can develop their speaking skill through watching English movies. Being students of English major, ability to speak English fluently is one of the most important things they have to get better at time to time. Based on the findings, they mostly have positive responses on how English movies affect speaking skill development.

They believe that they are able to apply better pronunciation through English movies. They do not only believe that they learn better pronunciation by listening, but movies also stimulate them to do better pronunciation in practice. They mostly believe that they are able to apply new vocabularies in practice through movies. With good intention about their motivation in watching English movie, this could not only help students improve listening skill, but also their speaking skill development. This is a good point where movies both introduce the students to new words and it motivates them to use the words in daily conversation practice.

In the thought of being able to apply unfamiliar accents and dialects better in practice, most of them only moderately think they could do that though. Because understanding different accents and dialects is one aspect, but to practice other dialects and accents is a totally different one. Accent and dialect are more of native tongue typical language aspects; in practice, they are not easily applied by people in common, especially by EFL speakers.

Another point that they only moderately agreed is how they can apply unfamiliar idioms, proverbs, and slang better by watching movies. This point is pretty much on the same level with the previous one regarding unfamiliar accents and dialects. Idioms, proverbs, and slang are more natural for native speakers to use daily, but EFL speakers are not accustomed to using English idioms, proverbs, and slang in daily speaking fluently. With good listening ability and full understanding in watching movies, it could really help better in mastering the idioms, proverbs and slang in contextual daily conversation. 
They also believe that motion pictures in movies inspire them to practice better daily conversation. Movies being an audio-visual media, not only help the students understand conversation contextually by listening, but it also inspire them in practicing the conversation they learn in movies into daily English speaking practice. Especially as this is supported with the varied choices of students on movie genre preferences; with different genres, they could learn more daily conversation in different contexts, and they could put it into daily practice.

The concluding point in speaking skill development is most of them very highly believe that they can improve their speaking skill better than other media that are normally used in class. So not only the students are aware of the good impact from watching English movies in their language skills development, but they also think that movies are better than other media that are usually used in class. And overall, they believe that English movies are good for teaching speaking skill for students. Not only movies are good for listening class, but also speaking skill as well. The recapitulated point of the findings on watching movies in speaking skill development is the students believe that they can improve their speaking skill by watching English movies.

English major students' lives are clearly involved with the English language most of the time, they have to study in English at least three or four times a week, and some of them use English daily; therefore, good English skill is important, especially oral skills. They are exposed to various kinds of media that can be used to improve their skills; however, English movies seem to be the chosen media. According to a study by Narat Winiyakul (2009), the movie was chosen because it is easy and fun. Also, it is considered easy because visual support such as videos, pictures, gestures, facial expressions, and body language can increase audiences' comprehension (Brown \& Yule, 1983) as the respondents claimed that motion pictures in the movies helps them understand the conversation better.

For the respondents, another factor that has an impact on their capability to comprehend the movies is the subtitles. Though they sometimes cause distractions, the respondents believe that English subtitles can increase their understanding of conversation in the movies. English subtitles can help students to identify the words that they are familiar with while the images will give a clue on the meaning. Also, with the majority of the respondents prefers English subtitles, meaning most of them can confirm their understanding of what they hear even without the translation texts.

According to Richard (1987), students should coordinate the oral, visual, and textual information together to learn new words, idioms, proverbs, and slang, and movies give examples of how those expressions are used in real life conversations. However, the levels of their understanding depended on the movie genre. Most of the respondents preferred action movies which are considered to be an appropriate choice, accompanied by romantic and comedy movies consisting of more conversation than horror or thriller movies. The speed of the conversation, whether fast or slow, also can affect the effectiveness of learning.

English movies are widely accepted as a teaching media, and the respondents claimed that movies can improve their listening and speaking skills better than other English media. However, instead of just watching, the textual dialogs of conversation should be provided for higher effectiveness. They mostly still believe that English movies are beneficial and they can definitely improve their listening and speaking skills by watching them.

Though by the looks of the averaged mean of both watching movies in listening skill development: 3.91 and in speaking skill development: 3.75 , it shows that listening skill is more 
directly related to English movies' impact. This finding is supported with the fact that the students pick listening skill as the most used skill in lives, followed by reading skill, and the third most used skill is speaking. But then again, with a good and focused intention of watching movies as shown in in the findings how $67.2 \%+11.9 \%$ of the students picked watching movies for language skill improvement, they could learn and apply more English skills better both in listening skill and speaking skill as well.

\section{CONCLUSIONS AND RECOMMENDATIONS}

1. English major students are aware that they can improve their listening skill by watching English movies. Subtitles can help respondents to understand conversation in the movies, and English movies are believed to be more effective than other media as teaching tools.

2. English major students believe that they can improve their speaking skill by watching English movies. Students think watching English movies has more direct influence to listening skill compared to speaking skill.

\section{RECOMMENDATIONS FOR FURTHER RESEARCH}

1. For more reliable results, future research should extend to various groups of people and the number of distributed questionnaires should be increased in order to support and validate the finding.

2. Due to the short time frame, this study collected data only from a questionnaire. Future studies might conduct interviews of students to gain more information or arrange a test of student listening and speaking skills.

3. Other interesting topics would be to study further about whether English subtitles or Indonesian subtitles is more effective as learning media, and also which movie genre is more effective in English skills development.

\section{REFERENCES}

Ahen, J. A. (2009). Student's Perception Towards English For Self Expression. Universiti Malaysia Sarawak. Retrieved September 22, 2016, from ir.unimas.my

Alonso, R. S. (2013). The Importance of Teaching Listening and Speaking Skills. Compultense University of Madrid: Spain. Retrieved May 25, 2015, from https://www.ucm.es

Anderson, R. H. (1976). Selecting \& Developing Media for Instruction. Wisconsin: American Society for Training and Development.

Brown, G., \& Yule, G. (1983). Teaching the spoken language: An approach based on the analysis of conversational English. Cambridge University Press.

Brown, H.D. (1994). Teaching by principles: an interactive approach to language pedagogy. Englewood Cliffs, NJ: Prentice Hall Regents.

Bueno, A, D. Madrid and N. McLaren, (eds). (2006). TEFL in Secondary Education. Granada: Editorial Universidad de Granada.

Burns, A., \& Joyce, H. (1997). Focus on speaking. Sydney: National Center for English Language Teaching and Research.

Chaney, A.L. (1998). Teaching Oral Communication. In: Grandes K-8. Boston: Allyn and Bacon.

Chenchen, X. (2011). How to Use English Movies to Improve a Student's Listening and Speaking Ability in Chinese ESL Culture Learning Classrooms. University of Wisconsin-Platteville, Platteville: WI. Retrieved May 19, 2015, from https://minds.wisconsin.edu

Dunkel, P. (1986). Developing listening fluency in L2: Theoretical principles and pedagogical considerations. The Modern Language Journal, 70 (2), 99-106.

Erita Budi, P. (2012). "Improving the Speaking Skill of the Tenth Grade Students At Sma Berbudi Yogyakarta By Using Videos in the Academic Year of 2011/2012” OpenTheses@Unsyiah_Lib, accessed December 15, 2016, http://uilis.unsyiah.ac.id/opentheses/items/show/106604. 
Liando, N. V. F., Sahetapy, R. J. V., \& Maru, M. G. (2018). English Major Students' Perceptions Towards Watching English Movies In Listening And Speaking Skills Development. Advances in Social Sciences Research Journal, 5(6) 1-16.

Farooq, U. (2014, July 31). Audio Visual Aids in Education, Definition, Types \& Objectives. Retrieved December 15, 2016, from http://www.studylecturenotes.com/curriculum-instructions/audio-visual-aids-in-educationdefinition-types-objectives

Gilakjani, A. P. \& Ahmadi M. R. (2011). A Study of Factors Affecting EFL Learners' English Listening Comprehension and the Strategies for Improvement. Journal of Language Teaching and Research, Vol. 2, No. 5, pp. 977-988.

Harmer, J. (2000). How to teach English. Beijing: Foreign Language Teaching and Research Press.

Harmer, J. (2007). The Practice of English Language Teaching. 4th ed. London: Longman.

Hornby, A.S. (1995). Oxford Advanced Learner's Dictionary. New York: Oxford University Press.

Howatt, A., \& Dakin, J. (1974). Language laboratory materials, ed. J. P. B. Allen, S. P. B. Allen, and S. P. Corder.

Ismiati, A. (2012). A Comparative Study of English Speaking Skill between Male and Female Students' on the First Grade Students of State Junior High School 5 Purworejo in the Academic Year 2011/2012. Universitas Muhammadiyah Purworejo: Central Java. Retrieved May 25, 2015, from http://www.aijcrnet.com/

Kijpoonphol, W. (2008). An investigation of difficulties related to listening comprehension: A case of university students. NIDA Language and Communication journal, 13, 30-51.

Lindsay, P. H. \& Norman, D. A. (1977). Human Information Processing. New York: Academic Press.

Lonergan, J. (1984). Language and languages; study and teaching; audio-visual aids. Cambridge University Press.

Perception Definition by Merriem-Webster. (n.d.). Retrieved December 17, 2016, from https://www.merriamwebster.com/dictionary/perception

Pimsamarn, T. (2011). A Survey of Students' Opinions on Watching English Soundtrack Movies to Enrich Listening Skill Development. Thammasat University: Bangkok, Thailand. Retrieved May 29, 2015, from https://digi.library.tu.ac.th

Richards, J. (1987). Listening comprehension: Approach, design, procedure. In M. Long \& J. Richards (Eds.), Methodology in TESOL: A book of readings. New York: Newbury House.

Rivers, W. (1966). Listening comprehension. Modern Language Journal 50(4): 196-204.

Roblyer, M. D., Doering, Aaron H. (2010). Integrating Educational Technology into Teaching (5th Edition). United States of America: Pearson Education, Inc.

Rubin, J. (1984). Using the educational potential of videodisc in language learning. CALICO Journal, 1 (4), 30 -34.

Sato, M. (2007). Exploring effective English teaching method using film scripts among poor learners of English. Waseda University, 218-231.

Thomlison, T. D., (1984). Relational listening: theoretical and practical considerations. $5^{\text {th }}$ International Listening Association. (pp.30) Scottsdale: AZ.

Van Duzer, C. (1997). Improving ESL learners' listening skills: At the workplace and beyond. Washington, DC: Project in Adult Immigrant Education and National Clearinghouse for ESL Literacy Education.

Wills, R. (2006). An investigation of factors influencing English listening comprehension and possible measures for improvement. University of Tasmania: Australia.

Winiyakul, N. (2010). Extracurricular use of English media to enrich the English language skills of first year students at Khon Kaen Univesity. Retrieved May 29, 2015, from https://digi.library.tu.ac.th

Xhemaili, M. (2013). The Advantages of Using Films to Enhance Student's Reading Skills in the EFL Classroom. Journal of Education and Practice Vol.4, No.13. Retrieved February 16, 2016, from https://www.iist.org 